\title{
HISTORY LEARNING IN INDONESIA DURING THE NEW ORDER
}

\author{
Umasih $^{1}$
}

\begin{abstract}
The three dominant components in the implementation of historical learning are teachers, students and curriculum. The Curriculum function as a teacher's references to outline the learning and its implementation in the classs. The initial is to develop a sef-awareness in order that the students will embrace high-spirited nationalism that will be implied to their daily life as a national and global citizen.

This article discuss on how the historical learning in High School implemented several curriculum in Indonesia. Thereforeurces data were obtained through research, observation, experince, and interview towards a number of history teachers from various of regions in Indonesia.
\end{abstract}

Key words: Historical learning, curriculum, contextual approach and cooperative learning.

\section{Introduction}

Since numerous of options of approach and learning model are offered, history teachers generally has not progress yet from tehir perspective of effective method. The implementation of historical learning based on Kurikulum Tingkat Satuan Pendidikan (KTSP) which ran more than four years, apparently, there are still thereforeme teachers who are confused on how to make Rencana Pelaksanaan Pembelajaran (RPP). Therefore, it creates an issues on how does historical learning implied in class?

There is almost no change in the implementation of the history teaching in Indonesia from one period to another. Since the 1975 curriculum was applied until KTSP year 2006, the learning orientation concluded by the teachers were still aiming to fulfill the curricullum objectives, not emphasising on what kind of competence the students will gained. Based on various of research through historical learning during those period, most of the result was far from what was expected.

\footnotetext{
1 Dr. Umasih, M. Hum., lecturer at the Departement of History Faculty of Social Science, Universitas Negeri Jakarta. This Article has been reviewed by Prof Bambang Purwanto (Gajah Mada University) and Prof Dadang Supardan, M.Pd (Indonesia University of Education).
} 


\section{The Objective of Historical Learning}

Historical learning has a fundamental function in shaping national integrity, human quality and Indonesia's community. As an educational support, historical learning is a normative teaching, because its goals and objectives are aimed at normative side, which are the value and meaning in accordance with history education's goal. It means that history meaning could be understood by the students if the educator (teacher) view history as a subject full with values. The values that should be developed are the ones that grow and develop in the life of students.

According to Collingwood, The essence of historical learning is about human nature and value. He stated that :

"... knowing your self means is knowing that you could do, and since nobody knows what he could do until he tries, the only clue to what man could do is what man has done. The value of history, then, is that is teachs us shat man has done and then what man is ...." (Collingwood, 1973;10)

Based on that statement, it could be concluded that history value stems from events and two or more ideas. Mindset has taught us about what human should do towards the existance of the human itself. The fundamental value of historical learning is directed to sense of enlightment in various aspects, such as developing sense of democratic and humanity, developing sense of honesty, fairness and willingness. Besides, it could altherefore develop sense of nationalism and patriotic, therefore the students will have the tendency to love and cherish their country, The Republic of Indonesia.

Traditionally, historical learning was meant as an effort to transfered the glory of nation in the past to the students. Therefore the historical learning is a media to inherit the distinguishing values of the nation. This historical learning meaning is surely important because it is the nation's contuanity of the past. However, the aim of it is not solely to inherited values. As it is stated by Hamid Hasan that the aims of historical learning are to:

1. Build the students' awareness on the importace of time and place which is a process from the past, now and future.

2. Practice the critic thinking of the students to understand historical facts correctly which is based on the scientific approach and methodology.

3. Develop appreciation and reward of the student towards historical objets as a proof of the existance of indonesian civilization in the past.

4. Grow students' understanding about the Indonesia's forming process through long history and still last till now and in the future.

5. Develop awareness to the students that they are parts of the Indonesia which has pride and nation love which could be implemented in life nationally or internationally (Hasan, 2010). 


\section{The Teachers Perspectived and Preordained on Historical Learning}

“... For me, the important thing is the students have the willingness to attend school,I am not saying that providing subject matter is unimportant, but it becomes the next objective after that.... " (Ratnaningsih, 205). This statement was conveyed by Ratna, a history teacher from one of the high school in the city of Makassar. The comment from Ratna is interpret that the method of learning is quite different from what history teachers preordaine in many areas which generally more focused on thereforelving the material. Generally, they felt the lack of time to complete the curriculum targets. As Preordanined, in the research on the the implementation of 1994 curriculum through high school history teachers (now High School) in West Java with respondents largely (9o percent) Educational background in history and even 65 per cent are University graduates, but 70 percent of them still felt the lack of time to pursue a curriculum based on the demands EBTA target (Hasan, 1997).

Difficulties in preparing the materials was altherefore expressed by Gandhi. It mainly was caused by: 1) the allocation of time available in the Outlines of the Teaching Program (GBPP) does not match the number of subjects, especially in first class, 2) non-standard GBPP nationally, 3) limited props as supporting the presentation of material as a whole (Gandhi, 1997).

The same difficulties experienced by Marlupi, history teacher who has undergone four changes to the curriculum $(1968,1975,1984$, and 1994). She said the curriculum was exessive of learning subject material, thus it caused difficulties in managing time. The text books that were available was not sycnchornize with the curriculum. The Curriculum in 1984 was even more unclarified, since the material was overlaped with the PSPB.(Marlupi, 2000)

The Lack of time justify the incomplete learning materials that has been continued even until now. Learning orientation is still on the mastery of the material rather than on students' competency in accordance with the principles and nature of the curriculum unit level of education (SBC). Therefore, teachers of history of DKI Jakarta, for example, through activities carried out in consultation subject teachers (MGMP) tries to pick and choose the essential materials. A point that could not be done at least by Ratna. She experienced difficulties in providing the material let alone pursue targets such curriculum is mostly done by teachers of any school. According to her, how could the subject matter will be well received by the student, when they attend to school often after taking an hazarddous substances. That is a reality in the implementation of our educational praxis that could not be avoided.

Ratna action by letting thereforeme students to attend school and studying in-class after taking a substances is not an educational thing that has a tendency to cause a scene. However, banning them to school, meaning that it will distinc them from the touch of education. The school rules and regulation in big cities like Jakarta has not been given the opportunites to not give space for students 
to make a change. Their parents and the surrounding community are familiar with the pattern of living like that: intoxicated, gambling, etc.Through education history is one of the solution (Ratnaningsih, 2005).

It seems that Ratna thinks far ahead, for her future students with the touch of love and education is more important than the students taught only the subject matter in order to pursue the target curriculum. What does Ratna did for most teachers who are not high-minded educators may be deemed to have done a riddicule. Amid the anxiety teachers facing charges "superior" for completing all the target curriculum and continually strive to deliver the material with a variety of strategies including oftenly giving st a quiz for students to succeed in exams. History subjects are not included in the subjects tested nationally, but what history teachers do not have anyone with that teachers do other subjects. One of the favorite high school in Jakarta and even accelerate the Standard subjects content of Ujian Nasional (UN) to 5 semester course and for History courses must be completed within two years, the class X and XI.(Umasih, 2010).

Learning strategies used by history teachers from a curriculum that one period to the next period may be referred to as the approach is. Even when the curriculum has been developed by educational units and teachers in curriculum and creative learning models-introduced many innovative start. As a result, no changes were significant (at least from the observation of several history teachers high schools in Jakarta in conjunction with the implementation of PPL students and teacher competency tests in 2005). Potential students, the experience brought from home and experience to learn the history of previous classes and text books are brought to class, not maximazing utilized by teachers to develop course material. (Supriyatna, 2007:59)

In Pati, several school principals and vice affairs curriculum acknowledges the history teachers are less innovative creative. Indeed there could not be ignored that teachers who dare to innovate, using a variety of cooperative learning model for active students and teachers are not the only thereforeurce of learning. Same as happened in Pati as disclosed Sayono, actually there are altherefore teachers of juniors who show creativity in concocting the material, therefore the subject matter presented in front of more students (Sayono, 1995:152-54).

Young teachers or teachers who are creative and innovative, they realize that the philosophy of the development of curriculum requires teachers to change the paradigm, because teachers are not the only source of learning. Thus students are actively involved in learning history, for example through the constructivism approach that started many teachers do for learning achieve optimal results. Learning contextual history must not only textual. Contextual Learning depart on constructivist approach. According to these approaches, students learn to construct meaning (meaning) through interaction and interpret their environment. According Books, constructivist approach is how students could build perceptions and new concepts by using the evaluation conducted during the learning progress. The meaning and what is learned by students together with 
their life experiences and contexts. That's all constructed by students rather than by teachers (Brook and Brooks, 1999:101-118).

Another approach which may be done in the historical learning is cooperative learning. This approach could be done with various techniques and methods that have successfully increased the motivation of student learning and mastery of competencies. At least through experimental research and class action could be proved that the use of the learning model that requires active student as in cooperative learning to enhance motivation and learning outcomes in history.

Cooperative learning approaches depart from the thinking getting better together. Cooperative Learning Approach to place students as part of the cooperation system in order to achieve optimal results in learning. In cooperation enables the emergence of a positive perception about who is successful and the students themselves or with the help of others. Cooperative learning approach provide wider learning opportunities for students to solve a problem which encountered during the learning process. This approach could therefore help students to understand the material.

According to Trianto, the aim of the approach is to increase the participation of students, improve student performance in academic tasks, helping students understand difficult concepts, develop critical thinking skills, and provides the opportunity for students to interact and learn together with students of different background.(Trianto, 2007:42-44)

The use of cooperative learning approach was one of the solution to reduce boredom and disinterest students to learn history when the teacher using conventional methods like that are generally much used by teachers before the implementation of SBC. The vast majority of history teachers (95.7 percent) use the lecture method and lectures varied, although it acknowledged this method does not have the ability to develop curriculum goals in the history of higher cognitive and affective aspects (Hasan, 1997). They used the lecture method as the primary method, because generally they were worried about the lack of time in completing the curriculum materials. This means that what is written in the curriculum document to use the process skills approach or CBSA does not match that happened on the actual situation (Hasan, 1991).

The results of the research conducted by Sayono in 1995concluded that the approach that was used by the teachers tend to mono-dimensional - political, following thelogicpreparationhandbook, rarelypresentsand discussesthematerial taught from different political viewpoints, economic, thereforecial, and cultural. Even in the observation of the author, such an approach continues to take place in most teachers today. Learning strategies tend to be monotonous in the sense of seldom encountered any variation made by the teacher. "Strategy nopo Pak, at best ningali nggih catetan, kapengker week dumugi purse, utawi ningali sat mops, Grandma mboten males, thereforemetimes Maos mbejang badhe dipun ingkang material discussed" (What strategy Sir, mostly, looking at the note last week or satpel, if I'm not lazy sometimes I read material that will be discussed tomorrow). 
(Sayono, 1995). In that way, how could teachers sosialize high school students to think critically, analytically as expected from the historical learning objectives.

Taufik Abdullah gives assessment of the implementation of the teaching of history in Indonesia in general. According to him, pedagogical strategy History of Indonesia is very weak. Education is still struggling in school history on cronicle approach and tend to require children to memorize an event. In fact it takes exactly how the child interprets the event in order to understand the dynamics of the changes. In high school, it is necessary to understand history as a tool for all kinds of events that occurred. Students at high school level are taught to dialogue with environment, picking existing problems, therefore they would understand the dynamics of a change (Abdullah, 1998).

In addition, a teacher with their teaching ability should understand the students and manage the class situation. In bringing the history lesson into the nuances of a new, more attractive and therefore connecting historical events with current events and conditions, as a result the students could be"encouraged" to explore further the knowledge of history is obtained, instead of "being asked". Thus automatically teacher could make students think critically and rationally.

In addition learning history must consider the interests of students by developing their intellectual abilities, that could developed sense of nationhood and pride in the accomplishments of the past glorious nation. To increase the potential for students to think not only by memorizing everyone, anytime and anywhere, but that need to be more stable and often do is to explain "how and why" of historical events. High school students must be trained in higher cognitive aspects of knowledge.

Although in various areas showed the presence of pedagogical weakness, high school history teacher in Semarang Municipality showed creativityly rather different. Pramono conduct a research with a sample of 220 people student. The research concluded that high school students' perceptions towards the teaching of history belong in the classification is good enough. It is seen from the purpose of teaching, of the material presented, teachers 'mastery of teaching materials, teacher planning, learning management, election methods, teaching media, assessment systems, teachers' motivation and Character aspects.(Pramono, 1993)

The above situation is different with the results of research conducted by Diana Nomida in Jakarta, which concluded that over 50 percent school students less interested in studying history, more than 50 percent teachers have difficulty in finding a source of learning. Teaching materials that presented only a series of facts without review of essential concepts contained much less historical significantant in that fact (Nomida, 1990).

The results of the research conducted by Pramono seem to reinforce the belief that learning Indonesian history could be improved, as long as the teachers willing to learn, open to renewal and want to explore their skills for performance improvement towards a professional teacher. Thus what happens in the learning of history in Indonesia is no longer likely that happen before the 
application of SBC. The implementation of curriculum and pedagogical strategies of history education is still weak, how history teachers could develop the ability to think processual, the attitudes of the students which is proud to be part as the Indonesian nation and the world community.

Various research seems supportive what concerns the history of education experts and learning phenomenon historian about the history that happened in the field. Hamid Hasan, for example, explained that the fact that there are now models of history teaching far from hope to enable children to see its relevance to contemporary life and the future. Both in elementary through high school level, education, history tends to utilize only the facts of history as the main material. No wonder that the education here was dry, uninteresting, and does not provide an opportunity for students to learn to explore the meaning of an historical event (Hasan, 1996).

The result of the implementation of curriculum evaluation is done high school history teachers in thereforeme of the region generally had not shown compliance with the desired curriculum. This is certainly not thereforelely because the incapability of the teacher, but in addition to the various constraints as mentioned above, high school history teachers altherefore experienced its own difficulties in the operational curriculum. Numerous things that are not profitable for the presence of history teacher today. First national policy concerning, among others, the problem of distribution and dissemination of curriculum documents that are often not up to the hands of teachers, not to mention the existence of different interpretations among teachers with the developer, administration officials and supervisor in how interpret curriculum. Another policy is the final evaluation to the history of Schools not designated as a National Examination Test (UN). There is a tendency that students learn more interested in the UN group of subjects. Secondly, local policy / territory that is a problem Outlines of the Teaching Program (GBPP) a curriculum or syllabus for the term now SBC document attachments, Teacher (MGMP), and evaluation of increased class. Before the application of SBC, MGMP activities tended to be implemented to generate GBPP History and lattice tests used for all history teachers.

According to Hamid Hassan, such a strategy is not just decreasing the essence of history education curriculum in force, but therefore contrary to the basis and principles of education. Hasan pointed that the 1994 curriculum implementation in the various provinces have experienced a change that is reflected in the curriculum characteristics GBPP. In DKI Jakarta, West Java, and DI Yogyakarta, GBPP 1994 curriculum has been modified in such a way that it becomes GBPP previous curriculum (1984) . Thus, the philosophy underlying the development of the 1994 curriculum, which is to give freedom and respect that is high on the ability of teachers was not implemented . Lack of socialization curriculum seems to be a key driver of change in these GBPP. Teachers are not prepared to carry out the new curriculum because they are not getting enough information about the subject matter curriculum and are not trained to implement 
the existing GBPP. Therefore far uniformation of teachers is therefore strong through upgrading, monitoring and direction. It was to form the mental attitude of teachers, tether creativity and makes teachers afraid to disagree, because the difference is considered as a deviant behavior in the community or institution (Buchori, 1993).

In relation to the problems of socialization curriculum, Djoko Suryo has different experiences from the current situation leading up to and implementation of SBC, where socialization has been done either by the National Education Standards Agency (BSNP) and the Center for Education Curriculum Balitbang to various districts / cities in Indonesia. According to him, when the curriculum was complete I was not asked to explain, given for granted. Properly Curriculum Centre (Puskur) together with the Regional Office of Education and Culture to thereforecialize. That does not happen therefore it could not be understood by the teachers who educated mediocre. Therefore not grasp what the developer intended curriculum "Suryo, 1999). Socialization even if there are local initiatives, Puskur make any mistakes and then disseminated. In fact revamp curriculum to be followed by reform of teacher knowledge, therefore that teachers get the point and could apply the curriculum properly.

Worries of Djoko Suryo to the lack of teachers' understanding about curriculum developing ideas are proven. Head of Regional Office (Kakanwil) Ministry of DKI Jakarta, Nurdin Alwi, concluded that most School teacher (high school, high school term for the time) has not been able to understand the national education curriculum in 1994. From the evaluation results, the ability of teachers' understanding of the curriculum is less than 6 points when should they (the teachers Jakarta) became the standard for other areas. This is due not only teachers' ability and talent, but lack of socialization curriculum among high school teachers (Nurdin, 1999).

Habib Mustopo has altherefore conducted research in 10 coastal and inland areas of East Java on the implementation of IPS-History lesthereforens. The result, that understanding the history teacher of the curriculum is less. (Mustopo, 1983) Similarly, the evaluation has been done Balitbang Dikbud year 1983 on the implementation of curriculum 1975 to study the field of Thereforecial Science-History of otherwise less than optimal, less teacher tried to study the existing guidelines and support facilities that have not been adequate. It results in students' grades in the subject of history was still under 6 .

Another factor that contributes inhibit socialization curriculum is the teacher's own internal factors, teachers' mindset should altherefore change in line with the change in curriculum, development of science and technology. Therefore the curriculum change was a thousand times no good if teachers did not join the mindset changed. If it appears continuously as described above, changes or ideas and any idea that only grows from the top and could not be translated into the teacher language, it will not have much effect on improving the quality of education if the changes are only in the sense of the curriculum plan. 


\section{Conclusion}

History became one of the compulsory subjects that are given to high school students in every period of the implementation of the curriculum in Indonesia today. Altough the concern from the government towards the existence of the subject is rather less, but at least there is still a "special place" that through history education, Indonesian people especially the younger generation will be able to recognize his true identity, the identity of the nation as part of the world community. The school curriculum does not seem to have much impact on strategy and learning approach used by the teacher. Even history teachers still continue to comaplaint for shortages of time because of its orientation on the material target, instead of the competencies the students should mastered. Thus, it is impossible to move towards a professional history teacher when it is still a discource.

\section{REFERENCES}

Abdullah, T. "Learning Strategy of Indonesian History.” Kompas, 8 November 1998.

Anita, L. (2004). Cooperative Learning. London: Grasindo,

Brooks and Brooks. (1999). In Search of Understanding: The Case for Construstivist Classrooms. ASCD Alexandria, USA.

Buchori, M. (1993). "Loosen Bureaucracy, Make A Curriculum that Inspires". Kompas, March 4.

Collingwood, R. G. (1973). The Idea of History. London: Oxford University Press.

Dickinthereforen, et, al. (1984). Learning History. Melbourne: Heinemann Educational Books.

Hasan, S. H. (1991). Evaluation Implementation of Curriculum History in high school. Research Report. IKIP Bandung.

"The policy and implementation History In The Environment Department Education and Culture", paper presented in Symposium on Teaching History 25-28 Dec 1997.

'Not Available Claims Period: History Curriculum must be addressed'. Kompas, December 14, 1996.

Gandhi, I. M., "Historical Experience As a Teacher", paper presented at the Symposium on Teaching History on December 3 to 6 August 1993 in Pelabuhan Ratu

Kochhar, S.K., (2008). Learning History, Teaching of History. New York: Grasindo.

Mustopo, H. (1983). "Faces of the National History Education at the Secondary Education Level”. Research Report, IKIP Malang.

Nomida, D. (1990). "Profile of Learning History of The SMA DKI Jakarta. Research Report, IKIP Jakarta. 
Nurdin, A. "Majority of High School Teacher Do not Understand Curriculum." Media Indonesia, December 2, 1999.

Pramono. (1993). "Teaching History, Text Book, Student Attitudes, and Understanding of Meaning of History (correlational study in a city of Semarang SMA)." Thesis PPs UNS Surakarta KPK IKIP Jakarta.

Sayono, J. (1995). "History Teacher Professional Ability in Teaching" (Case Study Teaching History evaluative SMA) in Pati. Thesis PPs UNS Surakarta KPK IKIP Jakarta.

Supriatna, N. Construction Learning Critical History. Bandung: Historia Utama Press.

Suryo, D. "Lesthereforens of Good A Note", papers delivered in Teaching History Symposium held by Ditjarahnitra December 8 to 11 August 1993 in Sukabumi.

Trianto. (2007). Innovative Learning Models Oriented in Constructivistic. Jakarta: Prestasi Pustaka Publisher.

Umasih. "History of Education in Indonesia: A Study on Change in Curriculum History High School (High School) Year 1975-1994. Thesis, Faculty of Letters University of Indonesia, 2000. . (2008). Policy Implementation Position Junior-Senior High School Thereforecial Science Teachers in the Nine Provinces In Indonesia, the New Order Era, 1966-1998. Dissertation, Faculty of Cultural Sciences, University of Indonesia.

\section{Interview :}

Ratnaningsih on december $10^{\text {th }}, 2005$ in 18 High School in Makasar and also the write did it on purpose of Disertation. Ratna expressed her experiences as a history teacher since 1990.

Marlupi on August $28^{\text {th }} 2000$ in East Jakarta

Djoko Suryo on September 22th 1999 in Aryaduta Hotel Jakarta 